\title{
Editorial
}

\section{Judging quality in science}

$\mathrm{T}$ he joint inspection report by Australia, Peru and the United Kingdom, presented at the last ATCM in Stockholm, contained an unusual recommendation. On the basis of the science that they had seen at the research stations the inspection team had concluded that there was both very good science and very poor science being undertaken. They apparently believed that this pattern was probably true of the whole continent but needed a more expert examination. Their recommendation was that SCAR should undertake an in situ assessment of all scientific research in the Antarctic.

This proposal brought forth the expected cries of protest, asserting the right of sovereign states to organise and fund whatever science they chose as well as questioning the involvement of SCAR in any such assessment. What was not clearly articulated in the discussion was why countries would want to fund poor science, and what could be done to improve such a situation.

The methods used by the Consultative Parties to select and support science in the Antarctic are complex and varied, growing out of their bureaucratic traditions of governance, the interplay between science and politics in their national culture and the expectations of their national science community in terms of competition. In the USA and many European countries there are fiercely competitive grant awarding systems with international peer review, with less than $25 \%$ of applications being funded. In contrast there are other countries in which there is little or no independent review, and a large percentage of applicants are rewarded with small grants inadequate to achieve any useful science. The degree of rigor in reviewing of the programmes of national Antarctic institutes also varies in a similar fashion, with concomitant problems for some of clear political direction of research.

No-one should assume that the peer review system is without faults but it does seem generally to allow recognition of good ideas over bad, and avoid selection on the basis of special agendas. Systems without rigorous review favour poor science and cronyism and make political interference much easier.

Publication of papers in international journals is a good independent index of the quality of science undertaken by any country. On this basis there is clearly a wide range of capabilities amongst Consultative Parties, although it has to be recognised that all have apparently passed the test of making a significant and continuing contribution to Antarctic science. SCAR has already recognised that some countries lag behind the rest in both their selection and management of science and would benefit from assistance in developing their potential. The SCAR Fellowships are just one way for young scientists to benefit from working in another country whilst the new SCAR science programmes offer the opportunity of capacity building for any country.

So what can we learn from this attempt to stimulate discussion of science quality at the ATCM? Apparently any suggestion of criticism strikes at the heart of nationalism, that for some at least sovereignty is still far more important than good science (despite over 40 years of the Treaty) and that there is still not an adequately expert forum in the ATS to discuss science away from politics. Rather than dwell on these negative conclusion perhaps what we should celebrate is that, although the inadequacies of some national systems have wasted much of their investment in science, many others have succeeded despite the potential political pitfalls.

We already have peace in the Antarctic. More scientists in the ATCM delegations around the table would help to inform diplomats and lawyers about the second key element of the Treaty they should be working for - science. And it should be good science as well.

DAVID WALTON 
The editors and Antarctic Science Ltd wish to thank the following specialists who have assisted them by providing referees' reports and advice on papers received throughout the year:

\begin{tabular}{|c|c|c|c|}
\hline I.-Y. Ahn & R.J.M. Crawford & I. Hogg & M. Pilkington \\
\hline D.J. Alexander & J.C.S. Creuwels & C. Howard-Williams & D. Pirrie \\
\hline W. Arntz & R. Cuthbert & A.H.L. Huiskes & P.J.A. Pugh \\
\hline R. Bargagli & T. Daeschler & J. Jacobs & J. Quade \\
\hline R.W. Baird & R.A. Daniels & A. Jenkins & M. Raab \\
\hline C. Ballantyne & B. Danis & P. Jones & J.B. Riding \\
\hline M. Bell & T.A. Day & G. Kaufmann & P. Riisager \\
\hline J. Berge & R.J. Delmas & M.A. Kessler & M. Rist \\
\hline D.M. Bergstrom & K. Dennis-Bryan & M.A. Hindell & G. Robertson \\
\hline P.A. Berkman & D.L. Dettman & S. Kipfstuhl & T.L. Rogers \\
\hline M.N. Bester & E.W. Domack & M. Korte & R.M. Ross \\
\hline J. Boelhouwers & R.R. Eakin & M. Latasa & B. Sattler \\
\hline S. Boger & J.T. Eastman & A. Leventer & B.R. Schone \\
\hline M. Booth & F. El-Daoushy & P.N. Lewis & M. Seppala \\
\hline I.L. Boyd & C.W. Evans & R.I. Lewis Smith & G. Shellam \\
\hline G. Boucher & M. Fedak & A.G. Lewkowicz & M. Silver \\
\hline P. Boveng & A. Foldvik & K. Linse & V. Smetacek \\
\hline T. Brey & E. Fossat & J. Lloyd & V.R. Smith \\
\hline P.A. Broady & J. Francis & E. Lodolo & M. Sole \\
\hline E. Brook & P.M. Gaffney & A.-N. Lorz & B. Stallwood \\
\hline H.R. Burton & H. Gallee & J.A. Macdonald & D. Stockwell \\
\hline P. Bustamante & J. Gonzalez-Solis & J.M. McArthur & D.E. Sugden \\
\hline M. Canli & D.B. Gore & E. McBride & M. Tasker \\
\hline D.J. Cantrill & D. Goujet & A. McMinn & C. Teyssier \\
\hline M. Carron & M.N. Gratton & M. McQuoid & R.A.J. Trouw \\
\hline A. Carter & P. Guilizzoni & B. Meldal & J. Turner \\
\hline P. Catry & J. Hagstrum & I. Millar & C. Tweedie \\
\hline R. Cattaneo-Vietti & K.J. Hall & H. Miller & C. van der Veen \\
\hline Y. Cherel & L. Halsey & G. Milne & T.D. van Ommen \\
\hline M. Chiantore & E.S. Hansen & I. Mitchell & A. Vanreusel \\
\hline M. Chiappini & Bob Hawley & A. Moore & A. Wendt \\
\hline S.L. Chown & G. Herndl & A. Mylnikov & W. Westheide \\
\hline A. Clarke & K.J. Heywood & M. Nakada & D.A. Wharton \\
\hline P. Convey & D. Hikuroa & A.W. North & R. Worland \\
\hline L.J. Corcuera & R. Hill & C. Page Chamberlain & P. Wilby \\
\hline J.A. Crame & C. Hjort & M.A. Parada & E.J Woehler \\
\hline
\end{tabular}




\section{Antarctic Science Bursary}

Antarctic Science Ltd is the educational charity which owns the journal Antarctic Science. In pursuit of its educational aims the Board of Antarctic Science Ltd has decided to institute a new award from 2006 onwards.

ANTARCTIC SCIENCE BURSARIES are awards of up to $£ 5000$, made annually, to support promising young scientists, working in any field of Antarctic scientific research. The purpose of the award is to broaden the scope of an existing research project through

a) funding extra field or laboratory work,

b) purchasing/contributing towards the cost of a key piece of equipment,

c) funding international collaboration, or

d) funding attendance and a presentation at a key conference.

Applicants should be at post-graduate or post-doctoral level and less than 35 years of age and may be from any country. Applications must be submitted in English on a standard Antarctic Science Bursary form, which may be downloaded from the Antarctic Science website at www.antarcticscience.org

Applicants are requested to provide the following information:

The title and a brief description of their existing research project, in no more than 500 words, plus references and no more than two supporting illustrations.

A concise description of the extended research or visit for which the bursary will be used, in no more than 500 words, plus references and no more than two supporting illustrations. Applicants should make clear the relevance of the proposed research or visit to Antarctic research and indicate the aims and proposed deliverables.

A budget justifying the money requested.

A statement of endorsement by their supervisor or line manager, including a statement to the effect that the application is extra to work already approved or funded.

Applications must be received no later than 1st March of each year. Any applications received after the closing date will not be considered for an award in the stated year. Applicants will be notified of the outcome on 1st May of the award year.

Applications will be assessed, as necessary, by members selected from the current Antarctic Science Advisory Editorial Board and will be judged on innovation, likelihood of success, and value within the relevant field of science.

A condition of acceptance of the ANTARCTIC SCIENCE BURSARY is that the successful recipient must offer to Antarctic Science a first- or lead-author paper on or relevant to the purpose for which the award is made. Subject to satisfactory review by the usual processes, the paper will be published in Antarctic Science and the author identified as the winner of an ANTARCTIC SCIENCE BURSARY. The decision of the Board of Antarctic Science Ltd is final and no correspondence will be entered into. 
https://doi.org/10.1017/S0954102005002993 Published online by Cambridge University Press 


\section{Introduction}

\section{Welcome to a new SCAR}

Tn July 2004 the Scientific Committee on Antarctic Research (SCAR), which is the interdisciplinary committee of the International Council of Science (ICSU) that deals with Antarctica and the Southern Ocean, held its first Open Science Conference. The conference was a great success. Some 1200 scientists from all countries with polar - and in particular Antarctic - research programmes came together to discuss progress and directions in Antarctic science, and to plan their involvement in the forthcoming International Polar Year (IPY, 2007-2009).

The conference was a symbol of the new approach that SCAR has taken to energise, engage and stimulate the Antarctic scientific community, following an international review of SCAR's programmes and practices. Among other things, SCAR has also reorganized to focus the efforts of the Antarctic scientific community on a narrower range of pan-Antarctic strategic scientific research programmes that can really make a difference to providing knowledge about the region, understanding the processes active there, and, where possible, forecasting possible future change. It is by bringing the activities of national programmes together into these wider international efforts that SCAR adds value to national contributions. In 2004 the SCAR community defined five internationally peer-reviewed strategic scientific programmes that will be the focus for a great deal of national and international research activities in the high Southern Hemisphere latitudes for the coming decade. These programmes are: AGCS (Antarctica and the Global Climate System), ACE (Antarctic Climate Evolution), EBA (Evolution and Biodiversity in the Antarctic), ICESTAR (Inter-Hemispheric Conjugacy Effects in Solar-Terrestrial and Aeronomy Research) and SALE (Subglacial Antarctic Lake Environments). They will play a leading role in the research planned for the International Polar Year (2007-2009) and beyond.

The theme of the Open Science Conference was "Antarctica and the Southern Ocean in the Global System", reflecting the redefinition of SCAR's main objective as being: "to initiate, develop, and coordinate high quality international scientific research in the Antarctic region, and on the role of the Antarctic region in the Earth system".

This special issue of Antarctic Science beings together the keynote talks given during the 2004 SCAR Open Science Conference. They cover progress in exciting topics, and a wide range of disciplines, and point the way forward in key areas of research. As befits keynote addresses to an audience from many disciplines, they are written in a way designed to be readily intelligible to all.

Several of the papers in this Special Issue deal with the subject of changing climates and environments, a topic of increasing concern as the world warms, with unforeseeable effects on the Antarctic region. Eric Wolff explains the goals and progress of ice-coring, and provides exciting new results from the Dome $\mathrm{C}$ ice core drilled by the European Project for Ice Coring in Antarctica (EPICA). This new ice core provides a high-resolution record of Antarctica's climate history for almost a million years. The new data provide important insights on the variability of the climate system through time, and especially on a significant increase in the intensity of glacial and interglacial signals around 400000 years ago, and provide important constraints for climate models. Lloyd Peck looks in detail at the tolerances of individual organisms that are adapted to the Antarctic realm to the kinds of environmental change that seem likely in a warmer world. Antarctic benthic species appear less capable than species elsewhere of responding to warming in ways that would ensure their survival. Angelika Brandt shows that the present biodiversity of the Southern Ocean is a function of the cooling of the Antarctic environment following the breakup of the Gondwana super-continent, and of the 
adaptation of organisms to the new harsh conditions, and to the effects of the long series of advances and retreats of ice across the continental shelf during the Pleistocene period. Diana Wall looks at the biodiversity and ecosystem functioning in the terrestrial habitats of Antarctica, stressing the need for more research to be able to predict how these organisms and their ecosystems will be affected by global change. Phil O'Brien tackles environmental concerns, discussing the possible risks to marine mammals of using acoustic instruments on ships, for example to collect seismic data or to map the seabed. He notes that most scientific instruments pose a similar or lower risk to mammals than do normal shipping operations. In general, the use of acoustic instruments in the region is at a much lower level, and of lower intensity than elsewhere in the ocean, which means a significantly lower overall risk. Erik Ivins and Thomas James use a battery of new technologies to examine the way in which Antarctica is responding to the melting and thinning of its ice cover since the end of the ice age. They present a new ice history model that explains the timing and amounts of loss of ice in key regions, the origins of the formerly high levels of ice in mountainous areas, and the displacement of the groundling lines of floating ice shelves like that in the Ross Sea.

John Storey takes a different approach, describing the use of Antarctica as a platform for observing the stars. At high altitude, away from the zones where katabatic winds predominate, Antarctica's air is cold, still, dry, and stable, providing astronomers with a gain in sensitivity and precision of measurement that can exceed by two orders of magnitude what is possible at the best sites in temperate latitudes. Antarctica could become the preferred location for massive telescopes capable of detecting earth-like planets in other solar systems.

Finally, Chris Rapley describes the major planning effort that has been undertaken in preparation for a new phase of polar exploration and of understanding of polar processes that will take place during the International Polar Year (2007-2009), under the aegis of the IPY sponsors, ICSU and the World Meteorological Organisation (WMO).

The next SCAR Open Science Conference, in Hobart, Tasmania, in July 2006, will offer an opportunity to refine the new scientific research programmes and to assess progress in Antarctic and Southern Ocean research just before the beginning of the IPY, ad therefore should have a significant impact on what is done during the IPY.

With this issue of Antarctic Science we hope to write a new chapter in the ongoing story of SCAR and its influence on Antarctic and Southern Ocean science. This brief introduction will serve as an invitation to the wider scientific community to collaborate with SCAR in its well-focused scientific programmes, not only for the International Polar Year, but for the decade to come.

JÖRN THIEDE

(SCAR President)

Bremerhaven

August 2005 